\title{
Gas Seepage along the Edge of the Aquitaine Shelf (France): Origin and Local Fluxes
}

\author{
Livio Ruffine, ${ }^{1}$ Jean-Pierre Donval, ${ }^{1}$ Claire Croguennec, ${ }^{1}$ Laurent Bignon, ${ }^{2}$ \\ Dominique Birot, ${ }^{1}$ Anne Battani, ${ }^{3}$ Germain Bayon, ${ }^{1}$ Jean-Claude Caprais, ${ }^{4}$ \\ Nadine Lantéri, ${ }^{2}$ Denis Levaché, ${ }^{5}$ and Stéphanie Dupré ${ }^{1}$ \\ ${ }^{1}$ IFREMER, Unité des Géosciences Marines, 29280 Plouzané, France \\ ${ }^{2}$ IFREMER, Unité des Recherches et Développements Technologiques, 29280 Plouzané, France \\ ${ }^{3}$ IFREMER, Unité des Ecosystèmes Profonds, 29280 Plouzané, France \\ ${ }^{4}$ IFPEN, 1-4 avenue de Bois-Préau, 92852 Rueil-Malmaison Cedex, France \\ ${ }^{5}$ TOTAL, avenue Larribau, 64000 Pau, France
}

Correspondence should be addressed to Livio Ruffine; livio.ruffine@ifremer.fr

Received 26 January 2017; Accepted 8 March 2017; Published 25 July 2017

Academic Editor: Timothy S. Collett

Copyright (C) 2017 Livio Ruffine et al. This is an open access article distributed under the Creative Commons Attribution License, which permits unrestricted use, distribution, and reproduction in any medium, provided the original work is properly cited.

\begin{abstract}
During the scientific expedition GAZCOGNE2 at the Bay of Biscay nine gas seeps were sampled for the first time and their flux was measured using an in situ pressure-preservation sampler (PEGAZ, ${ }^{\circ}$ IFREMER). Overall, three sites were investigated to determine the nature and the origin of the gases bubbling at the seafloor and forming acoustic plumes into the water column, as this was the question raised from the first geologic study of the area. This has guided our study and accordingly corresponds to the main purpose of the present article. Thus, the molecular and isotopic $\left(\delta \mathrm{D}\right.$ and $\left.\delta^{13} \mathrm{C}\right)$ analyses revealed that the gas seeps were primarily composed of methane. Both methane and ethane are of microbial origin, and the former has been generated by microbial reduction of carbon dioxide. Heavier hydrocarbons accounted for less than $0.06 \% \mathrm{~mol}$ of the total amount. Despite the microbial origin of methane, the samples exhibit subtle differences with respect to the $\delta^{13} \mathrm{C}_{\mathrm{CH}_{4}}$ values, which varied between -72.7 and $-66.1 \%$. It has been suggested that such a discrepancy was predominantly governed by the occurrence of anaerobic methane oxidation. The PEGAZ sampler also enabled us to estimate the local gas fluxes from the sampled streams. The resulting values are extremely heterogeneous between seeps, ranging from 35 to $368 \mathrm{mLn} \cdot \mathrm{min}^{-1}$. Assuming a steady discharge, the mean calculated methane emission for the nine seeps is of $38 \mathrm{kmol} \cdot \mathrm{yr}^{-1}$. Considering the extent of the seep area, this very local estimate suggests that the Aquitaine Shelf is a very appropriate place to study methane discharge and its fate on continental shelves.
\end{abstract}

\section{Introduction}

Submarine natural gas seeps are the seafloor expression of gas migration from leaking deeply buried hydrocarbon reservoirs or shallow depth methanogenesis. Any seep may be composed of a single gas stream or several ones very close to each other such that they clearly define its perimeter. Submarine seeps, at cold seeps, occur worldwide along the continental margins and are usually related to geological structures with either positive reliefs such as submarine pingoes [1-7], carbonate concretions and pavements [8-11], and mud volcanoes $[9,12-18]$ or negative reliefs like pockmarks $[13,19-23]$. They also occur in seafloor-reaching fault areas at tectonically active regions without being associated with a specific relief [24-28].

The study of submarine natural gas seeps is in many aspects a timely subject for the scientific community and the offshore industry. First, they represent a significant source of emitted hydrocarbons, mainly methane, into the water column and perhaps the atmosphere [7]. In the current context of on-going climate change, it is therefore essential to locate them on continental margins and shelves and then to assess the fate of these hydrocarbons and quantify their potential contribution to atmospheric methane contents $[29,30]$. Second, they represent key locations for the development of microbial activity, which oxidizes hydrocarbon compounds, 
and supply, in turn, energy for symbiotic communities living near the seafloor [31-35]. Third, for the oil and gas industry, the detection of hydrocarbon seepages at the seafloor is indicative of the presence of either possible reserves that are economically exploitable or potential geohazards [3639]. Once a gas seep area is discovered, one of the major concerns is the determination of its origin. Marine sediments host microbes which degrade organic matter, and this leads to in situ production of light gaseous hydrocarbons at shallow depth [40-45]. Such gases are commonly called microbial gases and mainly consist of methane. When a submarine seep is linked to a petroleum system, the gases are primarily of thermogenic origin, resulting from the thermocatalysis of deeply buried organic matter [43, 46-49]. However, the two aforementioned gas types derive from organic matter; therefore they belong to biotic gases [43, 44, 48-51]. They represent by far the biggest hydrocarbon sources on earth. Besides, hydrocarbons with an abiotic origin may contribute to the composition of seep gases [52]. They are produced from either magmatic processes (mantle-derived compounds) or postmagmatic processes (gas-water-rock reactions).

Furthermore, methane discharge in the ocean is thought to have been responsible for climate change in the geological past [53-56]. However, the mechanisms governing the fate of methane and other hydrocarbons into the water column are still under debate, and their probability to reach the atmosphere seems to be site-dependent [57-64]. Accordingly, although difficult, quantifying the contribution of oceanic methane to the global atmospheric budget is crucial, and this necessarily requires knowledge of local methane fluxes from submarine seeps as input.

Recently, a new major seepage area has been discovered at the Aquitaine Shelf, off SW France [65, 66], with a large number of active gas discharges being observed at the seafloor. The present study combines geochemical data and in situ flux measurements that aimed at determining both the nature and origin of the emitted gases and discussing the local methane discharged within the water column.

\section{Description of the Study Area}

The study area is located in the Bay of Biscay, within the offshore extension of the Parentis Basin [65]. The latter is the most prolific hydrocarbon basin in France [67]. Early acoustic surveys carried out during the expeditions Pegase 98/Pelgas 2000-2011, originally devoted to the evaluation of fish stock and recently examined for the detection of fluid emission, revealed that the seep area is located at water depth ranging from 140 to $185 \mathrm{~m}$ [65] (Figure 1). New acoustic surveys conducted in 2013 during the GAZCOGNE1 expedition aimed to better define the extent of the seep domain which appears to stretch over $\sim 80 \mathrm{~km}$ length at the edge of the Aquitaine Shelf, along a north-south oriented axis, and up to $8 \mathrm{~km}$ (5 km an average) in West-East [66].

Three sites have been selected on the basis of both the occurrence of gas emissions detected acoustically in the water column and their location with regard to the Parentis Basin and Landes High (Figure 1). They have been investigated by the remotely operated vehicle (ROV) Victor-6000 in the

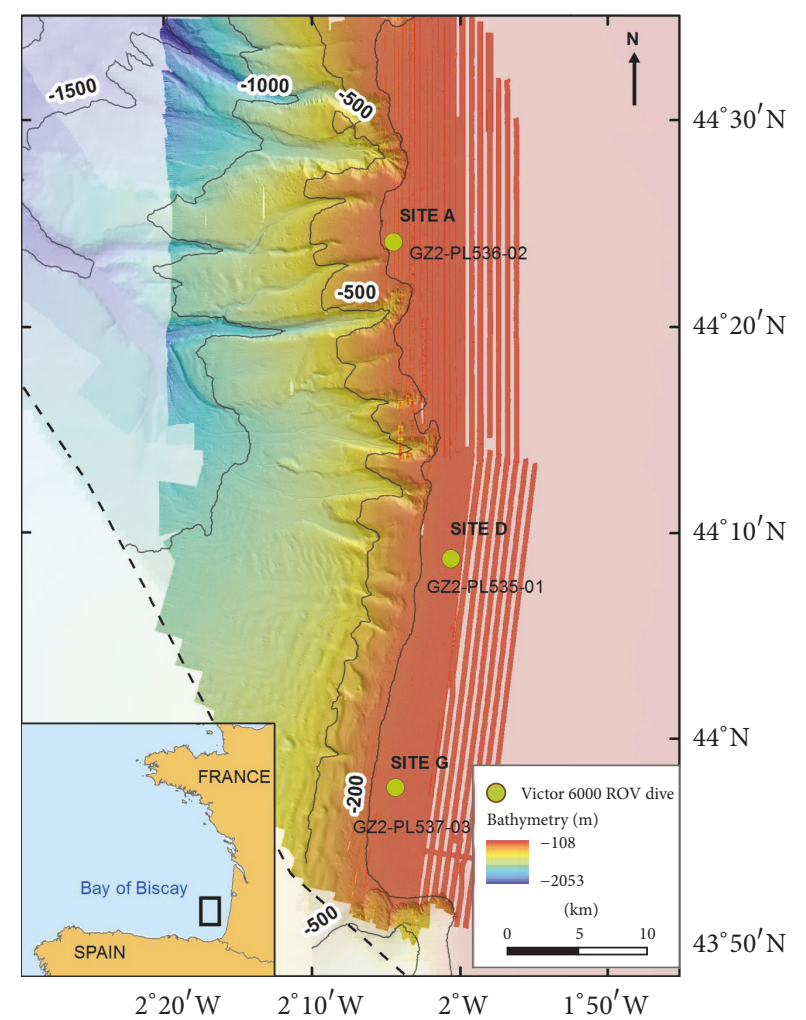

FIgURE 1: Location map of the study area.

frame of the GAZCOGNE2 expedition on board the R/V Pourquoi pas?. Apart from the plethora of fishes populating the bottom water, the sites were characterized by the presence of methane-derived carbonate pavements $[68,69]$ capable of covering surface areas of few meters square on the seafloor (Figure 2). Gases were bubbling through these carbonate pavements to the water column at most of the seeps. Gas seeps were also found within bacterial mats, with no outcropping carbonate pavements. However, push-core deployment for sediment sampling revealed the presence of carbonates covered by sediments beneath the bacterial mats, which hindered the sampling and led to unsuccessful core recovery [66].

A total of nine gas streams have been sampled from different seeps as shown in Figure 2. Site A, the northernmost one, was the less acoustically active site as the overall density and amplitude of the gas-related acoustic anomalies were less important. Two gas seeps were sampled there (GZ2p1536-PZ01-06 and GZ2-pl536-PZ02-08). At site D, three gas seeps have been sampled (GZ2-p1535-PZ01-01, GZ2-pl535PZ02-03, and GZ2-pl535-PZ03-05). The southernmost site, called site G, was the most acoustically active one. It was characterized by gas seeps close to each other and easier to find with the ROV. Thus, four gas streams have been sampled at site G (GZ2-pl537-PZ01-09, GZ2-pl537-PZ02-11, GZ2-p1537-PZ03-13, and GZ2-p1537-PZ04-12).

\section{Sampling and Methods}

3.1. In Situ Gas Sampling. During the GAZCOGNE2 cruise, gas samples were collected using a gas-bubble sampler called 

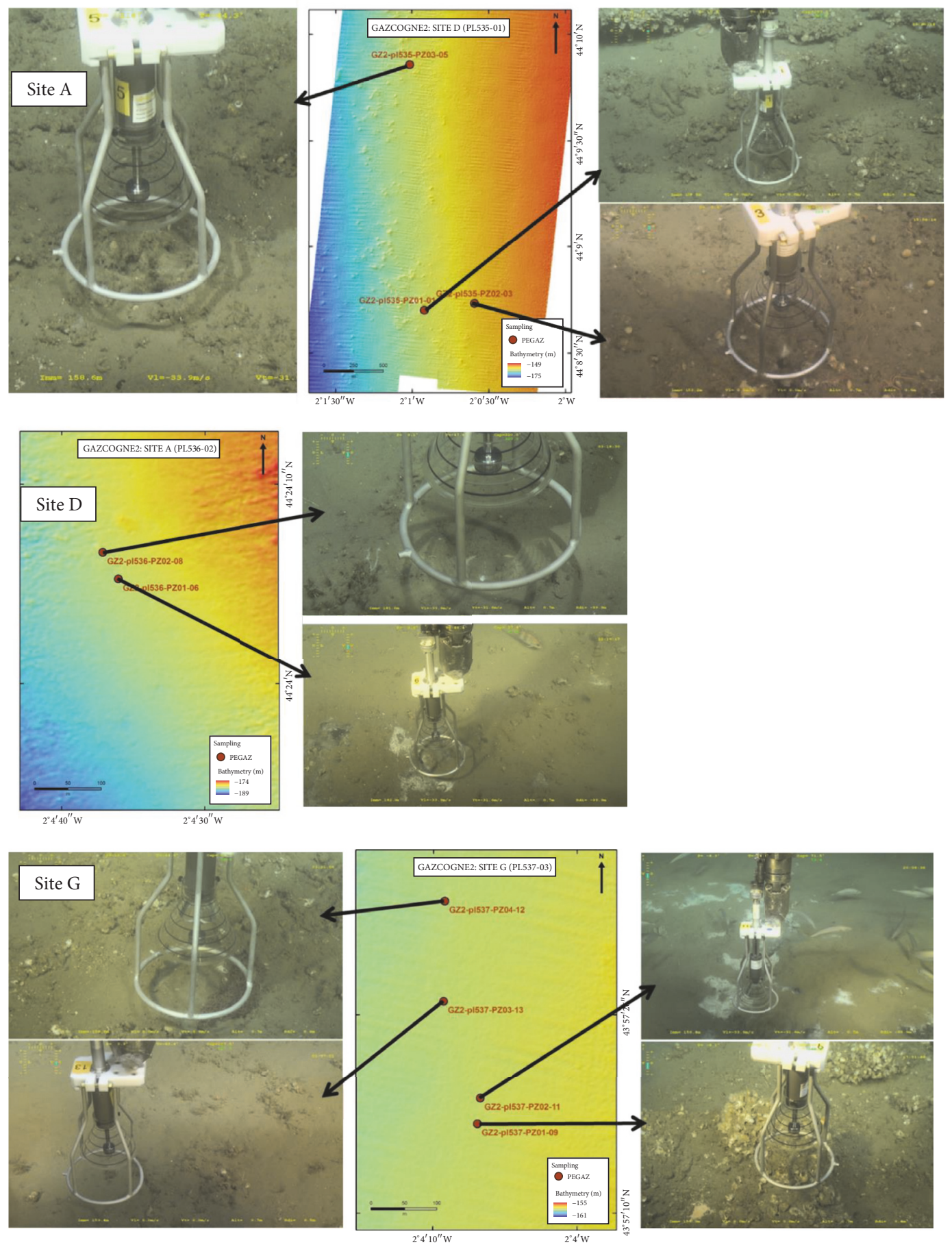

FIgUre 2: Dives on sites D, A, and G with the corresponding sampled seeps.

PEGAZ (PrElèvement de GAZ), designed and built at the Unité de Recherches et Développements Technologiques (RDT) of IFREMER [70]. Several gas-tight samplers have already been proposed in the literature for application to cold seep and hydrothermal systems [71-75]. Although their reliability has been proven from repeated deployments, they are characterized by a heavy weight ( $>5 \mathrm{~kg}$ in air) and may require either two pressure chambers including one pressurized with fluid prior deployment or electrical control. Our gas-tight sampler was developed in order to correct these weaknesses. Thus, it allows an easy and fast deployment, depression-free fluid sampling with minimization of the associated seawater volume in the case of gas sampling, and can be operated at most sea bottom temperature range and 


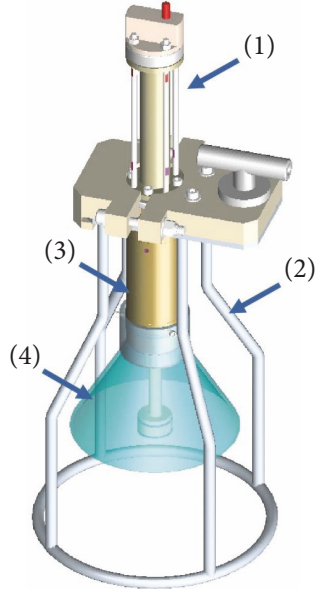

FIgURe 3: Picture of the PEGAZ gas-bubble sampler: (1) triggering system, (2) chassis, (3) high-pressure cylinder, and (4) funnel.

for water depth varying from 30 to 3000 meters. Briefly, including the frame, PEGAZ is $522 \mathrm{~mm}$ high and $\sim 210 \mathrm{~mm}$ in diameter and weighs only $2.7 \mathrm{~kg}$ in air (Figure 3). The $50 \mathrm{~mL}$ sampling cell is made of Teflon ${ }^{\circledR}$-coated titanium TA-6V. It consists of a central shaft ended with a piston and a cylindrical wall with a graduated PMMA funnel attached at its bottom, allowing gas flux measurement during sampling.

3.2. Analytical Methods. After recovery, the PEGAZ sampler was connected to a gas transfer system on board for subsampling [19]. The collected gases were stored at $\sim 3$ bars in $12 \mathrm{~mL}$ preevacuated vials from $\mathrm{Labco}^{\circledR}$. The latter was analyzed at the Laboratoire des Cycles Géochimiques et Ressources (LCG) of IFREMER for molecular composition. A gas chromatograph $\mu \mathrm{GC}$ R3000 from SRA equipped with a $\mu \mathrm{TCD}$ and a PoraPlot U capillary column was used for the determination of both methane and carbon dioxide concentrations. For the analysis of heavier hydrocarbons, a preconcentration method using activated silica at $-80^{\circ} \mathrm{C}$ was applied to separate the methane from the other hydrocarbons. The liquefied fraction of the sample was then analyzed on a gas chromatograph Agilent 7890 A equipped with a $32 \mathrm{~m}, 0.32 \mathrm{~mm}$ Porapak Q column. The uncertainty in the measurements was of $\pm 2 \%$ for methane and carbon dioxide concentrations and $\pm 4 \%$ for the heavier hydrocarbons. Subsamples were sent to the laboratory Isolab (Netherlands) for carbon and hydrogen stable isotope analyses. The analyses were carried out on gas chromatograph-isotope ratio-mass spectrometers (GC-IRMS). Stable carbon isotopes of methane and carbon dioxide were analyzed with an Agilent $6890 \mathrm{~N}$ gas chromatograph interfaced to a Finnigan Delta S IRMS using a Finnigan GC-C II interface from Thermo. The GC was equipped with a $12 \mathrm{~m}$ length and $0.32 \mathrm{~mm}$ diameter MolSieve column from Agilent and an injection valve. The minimum concentration required was $25-50 \mathrm{ppm}$. Stable carbon isotopes of ethane and propane were analyzed on an Agilent 7890A gas chromatograph interfaced to a MAT 253 IRMS using a GC-Isolink or a Finnigan GC-C III interface. The gas chromatograph was equipped with a $25 \mathrm{~m}$ length and $0.32 \mathrm{~mm}$ diameter Porabond-Q column from Agilent and an injection valve. Cold trapping was also used here to preconcentrate the sample when necessary. The $\delta \mathrm{D}$ measurements were done on an Agilent 7890A gas chromatograph interfaced to a MAT 253 IRMS and using a GC-Isolink interface from Thermo. The gas chromatograph was equipped with a $25 \mathrm{~m}$ length and $0.32 \mathrm{~mm}$ diameter MolSieve column and an injection valve. Samples were run at least 3 times after which an average was calculated. They were calibrated regularly against a calibration standard and the values are presented as part per thousand (\%o) relative to the Vienna PeeDee Belemnite Standard (vPDB) and the Vienna Standard Mean Ocean Water (VSMOW) for $\delta^{13} \mathrm{C}$ and $\delta \mathrm{D}$, respectively. The uncertainties in the $\delta^{13} \mathrm{C}$ and $\delta \mathrm{D}$ measurements are given as $\pm 0.1-0.3 \%$ and $\pm 1 \%$, respectively.

\section{Results and Discussion}

The molecular and isotopic compositions of the sampled gases are listed in Table 1. All samples are characterized by very high methane content. This compound accounts for more than $99.948 \% \mathrm{~mol}$ of the gas mixtures. Carbon dioxide is the second most abundant component, whereas only traces of ethane to butane were measured. The stable carbon isotopic ratios are very heterogeneous $\left(\delta^{13} \mathrm{C}\right)$ and range between -72.7 and $-66.1 \%$ for methane $\left(\mathrm{CH}_{4}\right),-49.1$ and $-40.9 \%$ or ethane $\left(\mathrm{C}_{2} \mathrm{H}_{6}\right),-30.1$ and $-27.9 \%$ for propane $\left(\mathrm{C}_{3} \mathrm{H}_{8}\right)$, and -34 and $-14 \%$ for carbon dioxide $\left(\mathrm{CO}_{2}\right)$; and $\delta \mathrm{D}$ values for methane vary between -182 and $-178 \%$. Methane with the lightest carbon isotope comes from the two sampled seeps located at site $\mathrm{A}$, the northernmost site. The measured gas fluxes are highly contrasted from one seep to another and even between gas streams from the same seep, ranging from 35 to $368 \mathrm{mLn} \cdot \mathrm{min}^{-1}$ ( $\mathrm{mLn}$ being the volume brought at the ambient pressure) (Table 2).

4.1. Hydrocarbon Origin. Molecular and isotopic compositions of natural gas are commonly used to determine their origin. Figure 4(a) represents the methane versus ethane and propane concentration ratios as a function of $\delta^{13} \mathrm{C}_{\mathrm{CH}_{4}}$ (after Bernard et al. (1978)) for our samples. The gases emitted along the western edge of the Aquitaine Shelf clearly fall into the microbial domain. This is strengthened by Figure 4(b) which further confirms that the methane has been generated by the microbial reduction of carbon dioxide. Such a result is in agreement with calculated values from the study of the associated methane-derived authigenic carbonates collected both on the seafloor and from box-cores [69]. In addition, the plot of $\delta^{13} \mathrm{C}_{\mathrm{C}_{2} \mathrm{H}_{6}}$ versus $\delta^{13} \mathrm{C}_{\mathrm{CH}_{4}}$ shown in Figure 4(c) indicates that ethane is also generated from microbial process. The very low values of $\delta^{13} \mathrm{C}$ for carbon dioxide (Table 1) are indicative of an organic source, which, again, further proves a microbial origin for the gases. In fact, $\mathrm{CO}_{2}$ originating from inorganic sources is characterized by higher values of $\delta^{13} \mathrm{C}$ $[82,83]$. Thus, the two major hydrocarbon components of the emitted gases are of microbial origin. Components heavier than ethane $\left(\mathrm{C}_{3+}\right)$ are present in trace amounts in all samples. Their presence in our samples either reflects a very small thermogenic contribution of deep-seated reservoirs from the 


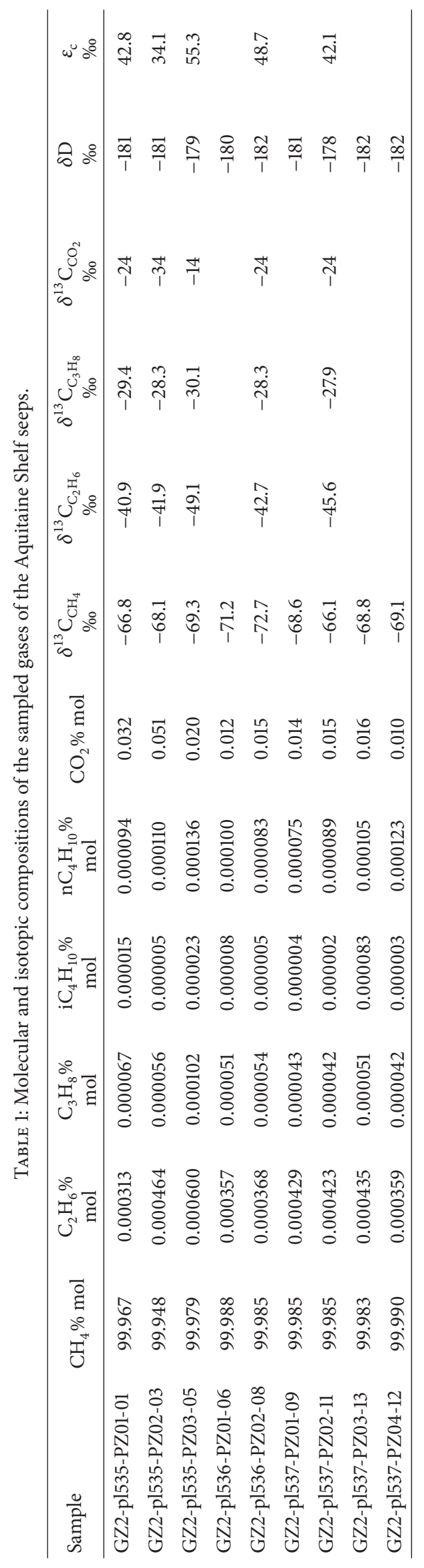




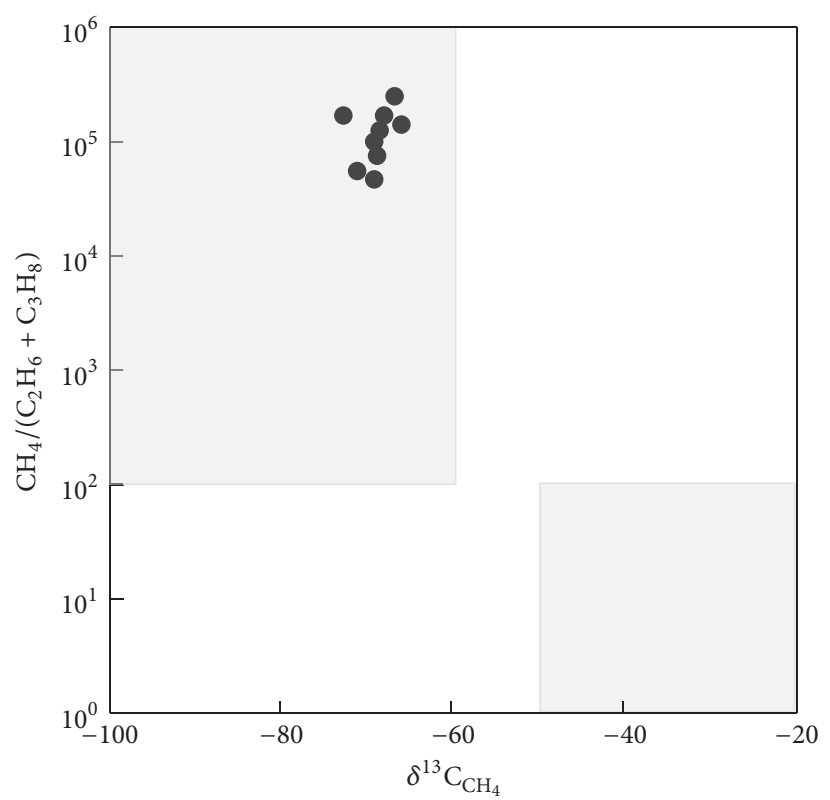

(a)

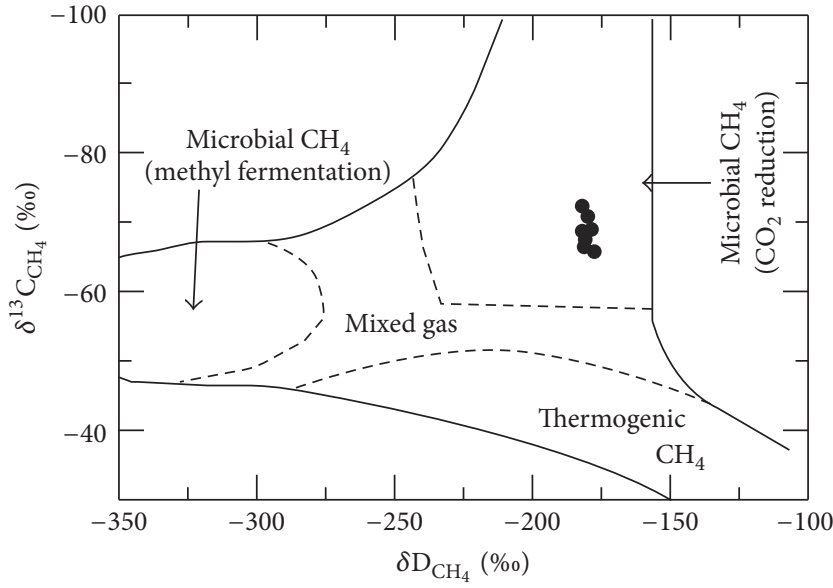

(b)

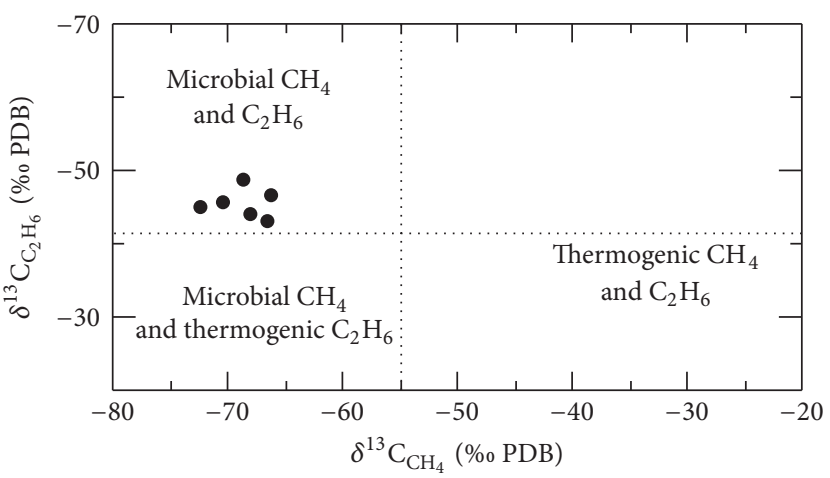

(c)

Figure 4: Diagrams for the study venting gases of the Aquitaine Shelf of (a) $\delta^{13} \mathrm{C}_{\mathrm{CH}_{4}}$ versus methane to (ethane and propane) molecular composition ratio (modified after Bernard et al., 1978); (b) $\delta^{13} \mathrm{D}_{\mathrm{CH}_{4}}$ versus $\delta^{13} \mathrm{C}_{\mathrm{CH}_{4}}$ (modified after Schoell, 1983, and Whiticar, 1999); and (c) $\delta^{13} \mathrm{C}_{\mathrm{CH}_{4}}$ versus $\delta^{13} \mathrm{C}_{\mathrm{CH}_{4}}$ (modified after Bernard et al., 1978).

Parentis Basin or are products generated at shallow depth and low temperature via microbial pathway [84-86]. Our dataset cannot allow us to proceed to a clear discrimination between these two sources [87-89]. However, the $\delta^{13} \mathrm{C}$ measured for both ethane and propane are close to values found for gases claimed as being microbial in the literature and lighter than values obtained from thermogenic-claimed gases $[16,82,87$, 90].

Because the study area is located within the offshore Parentis Basin, one may think that the microbial methane was generated from thermogenic hydrocarbons at reservoir level or during secondary migration by hydrocarbon degradation followed by methanogenesis [91-95]. Such biogeochemical processes lead to an enrichment in ${ }^{13} \mathrm{C}$ for both propane and carbon dioxide which are the main substrate for degradation and methanogenesis, respectively. This is not supported by neither Figure 5(a) nor Figure 5(b), where one can clearly see that $\delta^{13} \mathrm{C}_{\mathrm{C}_{3} \mathrm{H}_{8}}$ remains nearly constant with increasing $\mathrm{C}_{2} \mathrm{H}_{6} / \mathrm{C}_{3} \mathrm{H}_{8}$ ratio and $\delta^{13} \mathrm{C}_{\mathrm{CH}_{4}}$ does not decrease with increasing $\delta^{13} \mathrm{C}_{\mathrm{C}_{3} \mathrm{H}_{8}}$, respectively. Moreover, Figure 5(c) compares the isotopic patterns of two gas seeps characterized by biodegradation followed by methanogenesis (SoM_Western High and SoM_Central High which were collected on the Western and Central Highs in the Sea of Marmara, resp.) with our studied samples from the Aquitaine Shelf (Bay of Biscay) and a microbial gas seep (SoM-Cinarcik Basin) collected in the easternmost basin of the Sea of Marmara [87]. One can clearly see that the Bay of Biscay gas seeps have chemical 


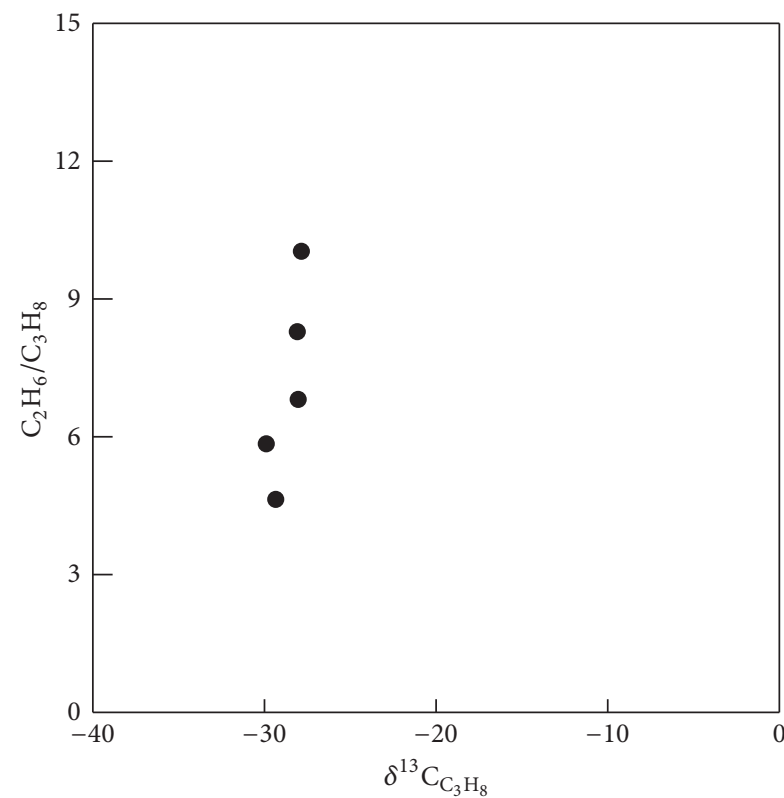

(a)

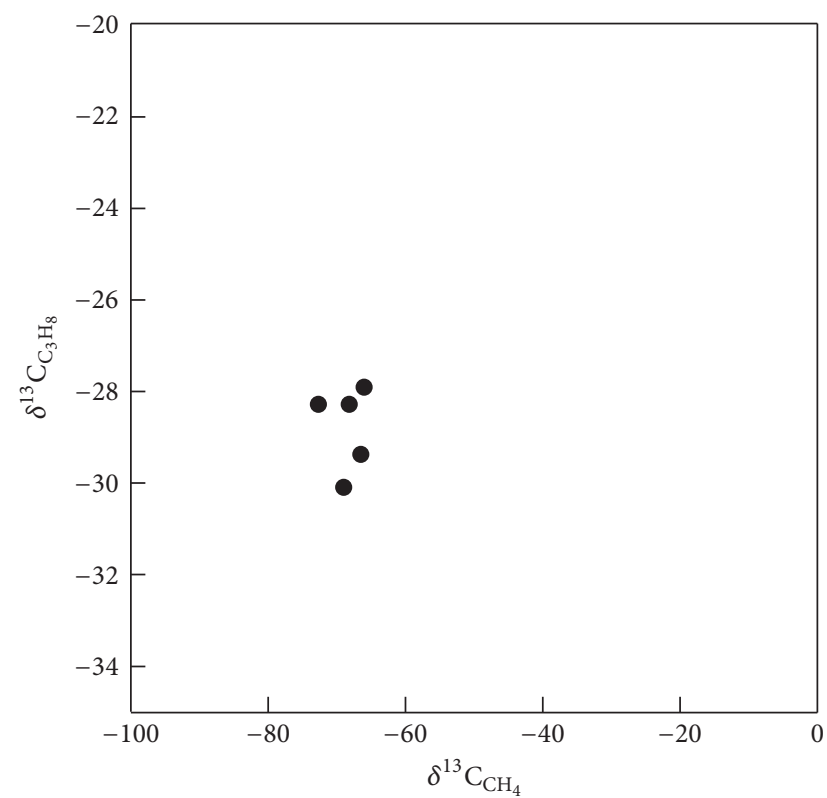

(b)

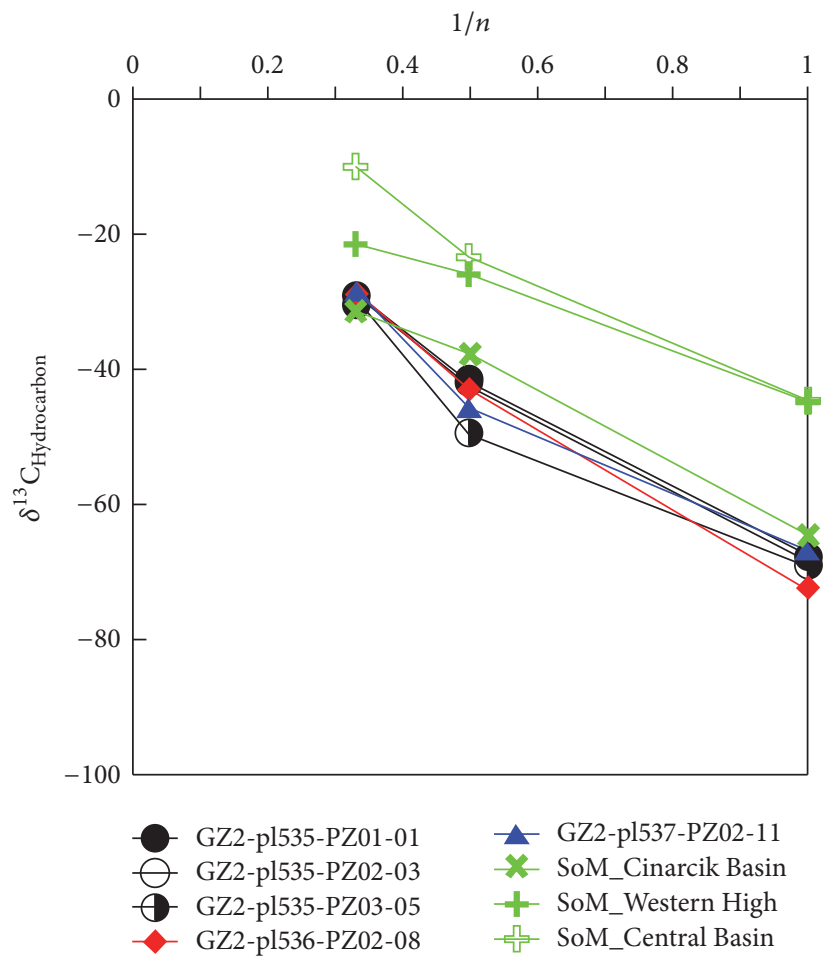

(c)

Figure 5: Diagrams for the study venting gases at the Aquitaine Shelf of (a) $\delta^{13} \mathrm{C}_{\mathrm{C}_{3}}$ versus ethane to propane molecular composition ratio (modified after Prinzhofer and Deville, 2013) and (b) $\delta^{13} \mathrm{C}_{\mathrm{C}_{1}}$ versus $\delta^{13} \mathrm{C}_{\mathrm{C}_{3}}$ (modified after Prinzhofer and Deville, 2013); (c) diagram of the reciprocal number of carbon atom in methane, ethane, and propane versus their $\delta^{13} \mathrm{C}$ for the study venting gases at the Aquitaine Shelf and other gas samples from the Sea of Marmara (after Chung et al., 1988).

pattern which is similar to the microbial gases collected in the Sea of Marmara. They are also characterized by close $\delta^{13} \mathrm{C}$ values. Thus, our results clearly indicate that the sampled seeps discharge microbial methane and ethane into the water column, though the origin of the $\mathrm{C}_{3+}$ fraction remains elusive.
4.2. Factors Affecting the Component-Isotopic Signatures. As mentioned earlier, the isotopic signatures of the different components are unevenly distributed from one seep to another. Several factors can contribute to this scattering $[44,96,97]$ such as the heterogeneity and the quality of 
TABLE 2: Gas fluxes measured from the nine gas streams sampled from the Aquitaine Shelf (normalized to the atmospheric pressure).

\begin{tabular}{lc}
\hline Sample & Flux/mLn/min \\
\hline GZ2-pl535-PZ01-01 & 341 \\
GZ2-pl535-PZ02-03 & 65 \\
GZ2-pl535-PZ03-05 & 306 \\
GZ2-pl536-PZ01-06 & 35 \\
GZ2-pl536-PZ02-08 & 136 \\
GZ2-pl537-PZ01-09 & 368 \\
GZ2-pl537-PZ02-11 & 199 \\
GZ2-pl537-PZ03-13 & 244 \\
GZ2-pl537-PZ04-12 & 51 \\
\hline
\end{tabular}

the substrates, the hydrocarbon-generation temperature, the occurrence of hydrocarbon oxidation coupled or not with carbonate precipitation, or multiple hydrocarbon-transport processes. Mixing of several gas sources can also lead to differences in the isotopic signatures as observed from our samples. However, mixing of several sources can be discarded here at the Aquitaine Shelf as the isotopic signatures of methane and ethane clearly show that they were generated by microbial processes. Moreover, even though there is a small thermogenic contribution, its amount would be so small that it would not explain such an important scattering for $\delta^{13} \mathrm{C}$ of methane. During microbial methanogenesis, the methanogens preferentially use the lighter carbon dioxide [44]. If the $\mathrm{CO}_{2}$ pool is severely depleted, it will mechanically be enriched in the heavier carbon and a shift in the $\delta^{13} \mathrm{C}_{\mathrm{CH}_{4}}$ towards higher values will be observed over time. However, the carbon fractionation factor $\varepsilon_{c}$, which is the difference between $\delta^{13} \mathrm{C}_{\mathrm{CO}_{2}}$ and $\delta^{13} \mathrm{C}_{\mathrm{CH}_{4}}$, should remain constant upon depletion [44]. Here, this factor varies widely within 34.1 and $55.3 \%$. Thus, it is unlikely that the quality or the heterogeneity of the substrate is the major factor responsible for the contrast in the $\delta^{13} \mathrm{C}_{\mathrm{CH}_{4}}$. Furthermore, in marine sediments, methanogenesis from microbial $\mathrm{CO}_{2}$-reduction usually leads to $\varepsilon_{\mathrm{c}}$ ranging between 49 and $100 \%$ [ [44]. The values obtained here fall below this range, except for the gas sample GZ2p1535-PZ03-05. Such low $\varepsilon_{\mathrm{c}}$ values may be partly explained by the fact that methane is transported by both diffusion as dissolved phase and advection of gas bubbles. Such two-phase transport is not surprising in gas seeps. However, methane advection in the gas phase is by far the dominant process due to the elevated gas fluxes measured (discussed in the following section); and the plot of $\delta^{13} \mathrm{C}_{\mathrm{CH}_{4}}$ as a function of the gas flux did not highlight any correlation. Thus, we believe that the two-phase transport cannot solely explain such an important scattering for both $\delta^{13} \mathrm{C}_{\mathrm{CH}_{4}}$ and $\varepsilon_{\mathrm{c}}$. The most convincing explanation remains the occurrence of biogeochemical processes, more specifically the Anaerobic Oxidation of Methane (AOM) coupled with carbonate precipitation within the sedimentary column $[31,40,44,98]$. This is in agreement with the isotopic signatures of the investigated MDAC (Pierre et al. 2017). The latter process preferentially takes up methane with the lighter carbon atom [99], therefore producing a ${ }^{13} \mathrm{C}$-depleted $\mathrm{CO}_{2}$ which leads to a decrease of $\varepsilon_{\mathrm{c}}$ as shown

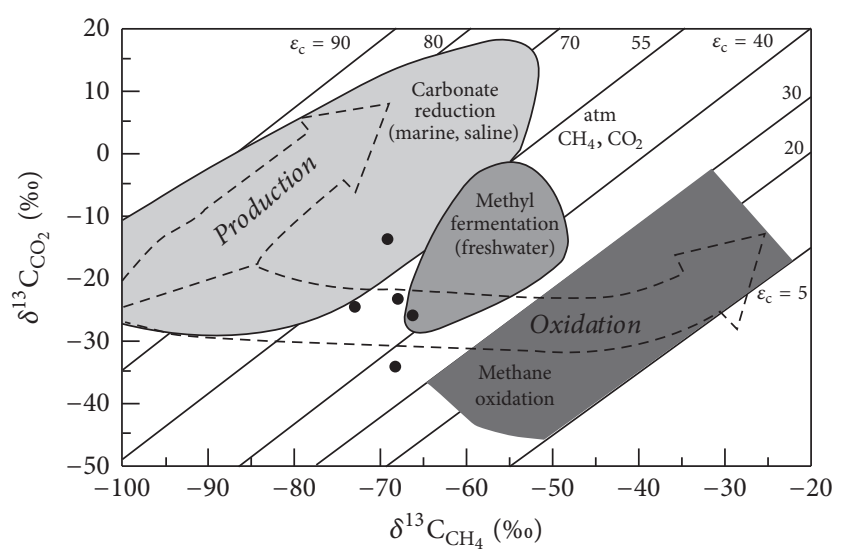

FIGURE 6: Diagram of carbon stable isotope composition of carbon dioxide versus methane for the study sites (modified after Whiticar, 1999).

in Figure 6. Pore-water geochemistry from cores would certainly allow us to get more insight into these processes; but reliable coring for pore-water geochemistry was unsuccessful due to the wide occurrence of carbonate pavements [69].

4.3. Local Methane Flux from the Nine Gas Streams. The occurrence of a large number of seeps with multiple gas streams in the shallow water of the Aquitaine Shelf for at least 18 years [65] raises questions about the amount of methane discharged into the water column. The unfavorable seafloor conditions for hydrate formation that prevail on the shelf (shallow water depth with bottom water temperature of $\sim 12^{\circ} \mathrm{C}$ ) discard the possibility of mitigating methane release by both storage as hydrate deposit and trapping of the migrating gas beneath the semipermeable hydrate-bearing layer.

As mentioned previously, each investigated seep was composed of several streams and only one stream was selected for gas sampling and flux measurement. The seeps were separated from each other to a couple of meters to tens of meters. In addition, disturbance of the sediment during the sampling by ROV created new and less vigorous gas streams, which may persist for the duration of the sampling. This indicates that the seep is frequently subject to both spatial and temporal variations. According to Table 2, the measured gas fluxes vary from 35 to $368 \mathrm{mLn} \cdot \mathrm{min}^{-1}$. These values are in the range of volumetric fluxes measured in the Central Nile Deep-Sea Fan in the Eastern Mediterranean Sea [76], the Kerch seep area in the northeastern Black Sea [79], and the convergent Makran continental margin [78]. However, these settings are located at much deeper depth than the Aquitaine Shelf. If one considers the gas composition given in Table 1 and assuming steady gas fluxes over time for the measured streams, about $38.2 \mathrm{kmol}$ of methane bubbles is annually discharged into the water column from only nine streams over thousands which create the numerous detected acoustic plumes [65]. At first sight, this value appears small compared to the estimates of gas fluxes from other settings like the aforementioned ones, the Hydrate Ridge [80] and The UK Block 15/25 [81] (Table 3). However it is important 
TABLE 3: Comparison of gas-bubble fluxes from different settings.

\begin{tabular}{|c|c|c|c|c|c|c|}
\hline Setting & $\begin{array}{l}\text { Water depth } \\
(\mathrm{m})\end{array}$ & $\begin{array}{c}\text { Gas flux } \\
\left(\times 10^{3}{\left.\mathrm{~mol} \cdot \mathrm{yr}^{-1}\right)}\right.\end{array}$ & $\begin{array}{c}\text { Flux measurement } \\
\text { technique }\end{array}$ & Gas origin & Comment & Reference \\
\hline Aquitaine shelf & $140-180$ & 38.2 & $\begin{array}{l}\text { Video recording of gas } \\
\text { bubbling through a } \\
\text { graduated volume }\end{array}$ & Biogenic & $\begin{array}{l}\text { Measurement for } 9 \\
\text { individual streams }\end{array}$ & This work \\
\hline $\begin{array}{l}\text { Eastern } \\
\text { Mediterranean Sea } \\
\text { (Hydrate site) }\end{array}$ & $1500-1800$ & $230-2300$ & $\begin{array}{l}\text { Combination of gas } \\
\text { analysis, ship-based } \\
\text { hydroacoustic surveys, } \\
\text { bubble size modeling, } \\
\text { and ROV observations }\end{array}$ & Biogenic & $\begin{array}{c}\text { Average } \\
\text { measurement for } \\
20 \text { individual } \\
\text { streams }\end{array}$ & {$[76]$} \\
\hline $\begin{array}{l}\text { Hakon Mosby MV } \\
\text { (Hydrate site) }\end{array}$ & 1250 & 6307 & ROV observations & Biogenic & $\begin{array}{l}\text { Measurement of } \\
\text { gas discharge from } \\
\text { open faults } \\
\text { and mud volcano }\end{array}$ & [77] \\
\hline $\begin{array}{l}\text { Makran continental } \\
\text { margin } \\
\text { (Hydrate site) }\end{array}$ & $575-2870$ & 10330 & $\begin{array}{l}\text { Combination of gas } \\
\text { analysis, ship-based } \\
\text { hydroacoustic surveys, } \\
\text { bubble size modeling, } \\
\text { and ROV observations }\end{array}$ & Biogenic & $\begin{array}{l}\text { Measurement from } \\
3 \text { gas flares } \\
\text { composed of } \\
\text { several streams and } \\
\text { extrapolation to all } \\
\text { identified flares } \\
\quad(>20)\end{array}$ & {$[78]$} \\
\hline $\begin{array}{l}\text { Don-Kuban paleo-fan } \\
\text { (Black Sea) } \\
\text { (Hydrate site) }\end{array}$ & 890 & $2000-87000$ & $\begin{array}{l}\text { Combination of gas } \\
\text { analysis, ship-based } \\
\text { hydroacoustic surveys, } \\
\text { bubble size modeling, } \\
\text { and ROV observations }\end{array}$ & Biogenic & $\begin{array}{c}\text { Average } \\
\text { measurement from } \\
\sim 600 \text { acoustic } \\
\text { flares over } 10^{6} \mathrm{~m}^{2} \\
\text { surface area }\end{array}$ & [79] \\
\hline $\begin{array}{l}\text { Northern summit of } \\
\text { Hydrate Ridge } \\
\text { (Hydrate site) }\end{array}$ & 1250 & 21900 & $\begin{array}{l}\text { Video recording of gas } \\
\text { displacing a fluid } \\
\text { through a PVC funnel }\end{array}$ & Biogenic & $\begin{array}{l}\text { Measurement for } \\
10 \text { individual } \\
\text { streams over } 80 \mathrm{~m}^{2} \\
\text { surface area }\end{array}$ & {$[80]$} \\
\hline UK Block 15/25 & 167 & 1064 & Gas rate measurements & Thermogenic & $\begin{array}{l}\text { Surveyed area of } \\
6.5 \times 10^{5} \mathrm{~m}^{2} \\
\text { surface area }\end{array}$ & {$[81]$} \\
\hline
\end{tabular}

to emphasize that our calculated value does not represent an estimate for the total amount of methane discharged into the water column over the widespread-seep area of the Aquitaine Shelf, an area with a surface $>60 * 10^{3}$ times bigger than the UK Block 15/25, for instance. It only corresponds to the cumulated values of nine highly localized discharges.

\section{Conclusion and Perspectives}

This paper reports on the first results of gas geochemistry from samples collected from submarine seeps at the Aquitaine Shelf (southwestern French margin). The origin and flux of the gases emitted into the water column were discussed. Our dataset indicated that the gases mainly contain methane, which was generated by microbe-mediated carbon dioxide reduction. Heavier hydrocarbons and carbon dioxide were present in trace and minor amounts, respectively. The gas fluxes of the sampled streams were very heterogeneous between each other, with values ranging in between 35 and $368 \mathrm{mLn} \cdot \mathrm{min}^{-1}$. Assuming steady discharge, the nine sampled streams release annually around $38 \mathrm{kmol}$ of methane into the water column. Knowing that thousands of plumes were detected from the water column acoustics, this puts forward the concern regarding the fate of the methane into the shallow water column of the Aquitaine Shelf. Such a study should deserve more considerations in future prospects.

\section{Conflicts of Interest}

The authors declare that they have no conflicts of interest.

\section{Acknowledgments}

The authors are grateful to the ROV Victor- 6000 team for the in situ sampling. The Captain of the Pourquoi pas? and his crew are also acknowledged for their technical support. The oceanographic expeditions GAZCOGNE1 (http://dx.doi.org/ 10.17600/13020070) and GAZCOGNE2 (http://dx.doi.org/ $10.17600 / 13030090$ ) as well as the study were financially supported by both IFREMER and TOTAL through the joint research collaborative project "Passive Margin Exploration Laboratories (PAMELA).” 


\section{References}

[1] M. Hovland and H. Svensen, "Submarine pingoes: Indicators of shallow gas hydrates in a pockmark at Nyegga, Norwegian Sea," Marine Geology, vol. 228, no. 1-4, pp. 15-23, 2006.

[2] M. Ivanov, A. Mazzini, V. Blinova et al., "Seep mounds on the Southern Vøring Plateau (offshore Norway)," Marine and Petroleum Geology, vol. 27, no. 6, pp. 1235-1261, 2010.

[3] C. K. Paull, W. Ussler III, S. R. Dallimore et al., "Origin of pingo-like features on the Beaufort Sea shelf and their possible relationship to decomposing methane gas hydrates," Geophysical Research Letters, vol. 34, no. 1, Article ID L01603, 2007.

[4] R. Sassen, H. H. Roberts, R. Carney et al., "Free hydrocarbon gas, gas hydrate, and authigenic minerals in chemosynthetic communities of the northern Gulf of Mexico continental slope: Relation to microbial processes," Chemical Geology, vol. 205, no. 3-4, pp. 195-217, 2004.

[5] C. Serié, M. Huuse, and N. H. Schødt, "Gas hydrate pingoes: Deep seafloor evidence of focused fluid flow on continental margins," Geology, vol. 40, no. 3, pp. 207-210, 2012.

[6] M. Hovland and A. G. Judd, Seabed Pockmarks and Seepages: Impact on Geology, Biology, and the Marine Environment, Graham \& Trotman, 1988.

[7] A. Judd and M. Hovland, "Seabed fluid flow: The impact on geology, biology, and the marine environment," Seabed Fluid Flow: The Impact on Geology, Biology, and the Marine Environment, pp. 1-475, 2007.

[8] Y. P. Bezrodnykh, S. V. Deliya, V. Y. Lavrushin, E. A. Yunin, V. V. Poshibaev, and B. G. Pokrovskii, "Gas seeps in the North Caspian water area," Lithology and Mineral Resources, vol. 48, no. 5, pp. 373-383, 2013.

[9] S. Dupré, J. Woodside, I. Klaucke, J. Mascle, and J.-P. Foucher, "Widespread active seepage activity on the Nile Deep Sea Fan (offshore Egypt) revealed by high-definition geophysical imagery," Marine Geology, vol. 275, no. 1-4, pp. 1-19, 2010.

[10] D. Feng, D. Chen, and H. H. Roberts, "Petrographic and geochemical characterization of seep carbonate from Bush Hill (GC 185) gas vent and hydrate site of the Gulf of Mexico," Marine and Petroleum Geology, vol. 26, no. 7, pp. 1190-1198, 2009.

[11] D. Fu Chen, Q. Liu, Z. Zhang, L. M. Cathles III, and H. H. Roberts, "Biogenic fabrics in seep carbonates from an active gas vent site in Green Canyon Block 238, Gulf of Mexico," Marine and Petroleum Geology, vol. 24, no. 5, pp. 313-320, 2007.

[12] V. N. Blinova, M. C. Comas, M. K. Ivanov, E. N. Poludetkina, and T. V. Matveeva, "Active mud volcanism in the West Alboran Basin: Geochemical evidence of hydrocarbon seepage," Marine and Petroleum Geology, vol. 28, no. 8, pp. 1483-1504, 2011.

[13] S.-C. Chen, S.-K. Hsu, C.-H. Tsai, C.-Y. Ku, Y.-C. Yeh, and Y. Wang, "Gas seepage, pockmarks and mud volcanoes in the near shore of SW Taiwan," Marine Geophysical Researches, vol. 31, no. 1, pp. 133-147, 2010.

[14] V. Mastalerz, G. J. de Lange, A. Dählmann, and T. Feseker, "Active venting at the Isis mud volcano, offshore Egypt: Origin and migration of hydrocarbons," Chemical Geology, vol. 246, no. 1-2, pp. 87-106, 2007.

[15] T. Pape, A. Bahr, S. A. Klapp, F. Abegg, and G. Bohrmann, "High-intensity gas seepage causes rafting of shallow gas hydrates in the southeastern Black Sea," Earth and Planetary Science Letters, vol. 307, no. 1-2, pp. 35-46, 2011.

[16] A. Prinzhofer and E. Deville, "Origins of hydrocarbon gas seeping out from offshore mud volcanoes in the nile delta," Tectonophysics, vol. 591, pp. 52-61, 2013.
[17] R. Shakirov, A. Obzhirov, E. Suess, A. Salyuk, and N. Biebow, "Mud volcanoes and gas vents in the Okhotsk Sea area," GeoMarine Letters, vol. 24, no. 3, pp. 140-149, 2004.

[18] L. Spulber, G. Etiope, C. Baciu, C. MaloS, and S. N. Vlad, "Methane emission from natural gas seeps and mud volcanoes in Transylvania (Romania)," Geofluids, vol. 10, no. 4, pp. 463-475, 2010.

[19] J. L. Charlou, J. P. Donval, Y. Fouquet et al., "Physical and chemical characterization of gas hydrates and associated methane plumes in the Congo-Angola Basin," Chemical Geology, vol. 205, no. 3-4, pp. 405-425, 2004.

[20] A. Gay, M. Lopez, C. Berndt, and M. Séranne, "Geological controls on focused fluid flow associated with seafloor seeps in the Lower Congo Basin," Marine Geology, vol. 244, no. 1-4, pp. 68-92, 2007.

[21] S. Hustoft, S. Bünz, J. Mienert, and S. Chand, "Gas hydrate reservoir and active methane-venting province in sediments on $<20$ Ma young oceanic crust in the Fram Strait, offshore NWSvalbard," Earth and Planetary Science Letters, vol. 284, no. 1-2, pp. 12-24, 2009.

[22] K. R. Newman, M.-H. Cormier, J. K. Weissel et al., "Active methane venting observed at giant pockmarks along the U.S. mid-Atlantic shelf break," Earth and Planetary Science Letters, vol. 267, no. 1-2, pp. 341-352, 2008.

[23] J. Iglesias, G. Ercilla, S. García-Gil, and A. G. Judd, "Pockforms: An evaluation of pockmark-like seabed features on the Landes Plateau, Bay of Biscay," Geo-Marine Letters, vol. 30, no. 3-4, pp. 207-219, 2010.

[24] P. M. Barnes, G. Lamarche, J. Bialas et al., "Tectonic and geological framework for gas hydrates and cold seeps on the Hikurangi subduction margin, New Zealand," Marine Geology, vol. 272, no. 1-4, pp. 26-48, 2010.

[25] D. Fischer, J. M. Mogollón, M. Strasser et al., "Subduction zone earthquake as potential trigger of submarine hydrocarbon seepage," Nature Geoscience, vol. 6, no. 8, pp. 647-651, 2013.

[26] L. Géli, P. Henry, T. Zitter et al., "Gas emissions and active tectonics within the submerged section of the North Anatolian Fault zone in the Sea of Marmara," Earth and Planetary Science Letters, vol. 274, no. 1-2, pp. 34-39, 2008.

[27] A. Hiruta, G. T. Snyder, H. Tomaru, and R. Matsumoto, "Geochemical constraints for the formation and dissociation of gas hydrate in an area of high methane flux, eastern margin of the Japan Sea," Earth and Planetary Science Letters, vol. 279, no. 3-4, pp. 326-339, 2009.

[28] T. A. C. Zitter, P. Henry, G. Aloisi et al., "Cold seeps along the main Marmara Fault in the Sea of Marmara (Turkey)," DeepSea Research Part I: Oceanographic Research Papers, vol. 55, no. 4, pp. 552-570, 2008.

[29] S. Schwietzke, O. A. Sherwood, L. M. P. Bruhwiler et al., "Upward revision of global fossil fuel methane emissions based on isotope database," Nature, vol. 538, no. 7623, pp. 88-91, 2016.

[30] M. Hovland, A. G. Judd, and R. A. Burke Jr., "The global flux of methane from shallow submarine sediments," Chemosphere, vol. 26, no. 1-4, pp. 559-578, 1993.

[31] A. Boetius, K. Ravenschlag, C. J. Schubert et al., "A marine microbial consortium apparently mediating anaerobic oxidation of methane," Nature, vol. 407, pp. 623-626, 2000.

[32] A. Boetius and F. Wenzhöfer, "Seafloor oxygen consumption fuelled by methane from cold seeps," Nature Geoscience, vol. 6, no. 9, pp. 725-734, 2013. 
[33] H. J. Mills, R. J. Martinez, S. Story, and P. A. Sobecky, "Identification of members of the metabolically active microbial populations associated with Beggiatoa species mat communities from Gulf of Mexico cold-seep sediments," Applied and Environmental Microbiology, vol. 70, no. 9, pp. 5447-5458, 2004.

[34] K. Olu, J. C. Caprais, J. Galéron et al., "Influence of seep emission on the non-symbiont-bearing fauna and vagrant species at an active giant pockmark in the Gulf of Guinea (CongoAngola margin)," Deep-Sea Research Part II: Topical Studies in Oceanography, vol. 56, no. 23, pp. 2380-2393, 2009.

[35] P. R. Dando and M. Hovland, "Environmental effects of submarine seeping natural gas," Continental Shelf Research, vol. 12, no. 10, pp. 1197-1207, 1992.

[36] P. Fleischer, T. H. Orsi, M. D. Richardson, and A. L. Anderson, "Distribution of free gas in marine sediments: A global overview," Geo-Marine Letters, vol. 21, no. 2, pp. 103-122, 2001.

[37] G. C. Sills and S. J. Wheeler, "The significance of gas for offshore operations," Continental Shelf Research, vol. 12, no. 10, pp. 12391250, 1992.

[38] N. Sultan, G. Bohrmann, L. Ruffine et al., "Pockmark formation and evolution in deep water Nigeria: Rapid hydrate growth versus slow hydrate dissolution," Journal of Geophysical Research: Solid Earth, vol. 119, no. 4, pp. 2679-2694, 2014.

[39] J. Thrasher, A. J. Fleet, S. J. Hay, M. Hovland, and S. Düppenbecker, "Understanding geology as the key to using seepage in exploration: the spectrum of seepage styles," AAPG Memoir, no. 66, pp. 223-241, 1996.

[40] R. O. Barnes and E. D. Goldberg, "Methane production and consumption in anoxic marine sediments," Geology, vol. 4, no. 5, pp. 297-300, 1976.

[41] G. E. Claypool and I. R. Kaplan, "The origin and distribution of methane in marine sediments," in Natural Gases in Marine Sediments, I. R. Kaplan, Ed., pp. 99-139, Plenum Press, New York, NY, USA, 1974.

[42] R. S. Oremland and B. F. Taylor, "Sulfate reduction and methanogenesis in marine sediments," Geochimica et Cosmochimica Acta, vol. 42, no. 2, pp. 209-214, 1978.

[43] M. J. Whiticar, "Correlation of natural gases with their sources," in The Petroleum System: From Sources to Trap, AAPG Memoir, L. B. Magoon, and W. G. Dow, Eds., vol. 60, pp. 261-283, 1994.

[44] M. J. Whiticar, "Carbon and hydrogen isotope systematics of bacterial formation and oxidation of methane," Chemical Geology, vol. 161, no. 1, pp. 291-314, 1999.

[45] M. J. Whiticar, E. Faber, and M. Schoell, "Biogenic methane formation in marine and freshwater environments: $\mathrm{CO} 2$ reduction vs. acetate fermentation-Isotope evidence," Geochimica et Cosmochimica Acta, vol. 50, no. 5, pp. 693-709, 1986.

[46] B. B. Bernard, J. M. Brooks, and W. M. Sackett, "Light hydrocarbons in recent Texas continental shelf and slope sediments," Journal of Geophysical Research-Oceans and Atmospheres, vol. 83, no. C8, pp. 4053-4061, 1978.

[47] H. M. Chung, J. R. Gormly, and R. M. Squires, "Origin of gaseous hydrocarbons in subsurface environments: Theoretical considerations of carbon isotope distribution," Chemical Geology, vol. 71, no. 1-3, pp. 97-104, 1988.

[48] M. Schoell, "The hydrogen and carbon isotopic composition of methane from natural gases of various origins," Geochimica et Cosmochimica Acta, vol. 44, no. 5, pp. 649-661, 1980.

[49] M. Schoell, "genetic characterization of natural gases," American Association of Petroleum Geologists Bulletin, vol. 67, no. 12, pp. 2225-2238, 1983.
[50] B. B. Bernard, J. M. Brooks, and W. M. Sackett, "Natural gas seepage in the Gulf of Mexico," Earth and Planetary Science Letters, vol. 31, no. 1, pp. 48-54, 1976.

[51] A. Waseda and H. Iwano, "Characterization of natural gases in Japan based on molecular and carbon isotope compositions," Geofluids, vol. 8, no. 4, pp. 286-292, 2008.

[52] G. Etiope and B. Sherwood Lollar, "Abiotic methane on earth," Reviews of Geophysics, vol. 51, no. 2, pp. 276-299, 2013.

[53] G. R. Dickens, M. M. Castillo, and J. C. G. Walker, "A blast of gas in the latest Paleocene: Simulating first-order effects of massive dissociation of oceanic methane hydrate," Geology, vol. 25, no. 3, pp. 259-262, 1997.

[54] J. P. Kennett, K. G. Cannariato, I. L. Hendy, and R. J. Behl, Methane Hydrates in Quaternary Climate Change: The Clathrate Gun Hypothesis, American Geophysical Union, Washington, D.C., USA, 2003.

[55] R. D. Norris and U. Röhl, "Carbon cycling and chronology of climate warming during the Palaeocene/Eocene transition," Nature, vol. 401, no. 6755, pp. 775-778, 1999.

[56] H. Svensen, S. Planke, B. Jamtveit, and T. Pedersen, "Seep carbonate formation controlled by hydrothermal vent complexes: A case study from the Vøring Basin, the Norwegian Sea," GeoMarine Letters, vol. 23, no. 3-4, pp. 351-358, 2003.

[57] L. Hu, S. A. Yvon-Lewis, J. D. Kessler, and I. R. MacDonald, "Methane fluxes to the atmosphere from deepwater hydrocarbon seeps in the northern Gulf of Mexico," Journal of Geophysical Research: Oceans, vol. 117, no. 1, Article ID C01009, 2012.

[58] J. D. Kessler, D. L. Valentine, M. C. Redmond, and M. Du, "Response to comment on "a persistent oxygen anomaly reveals the fate of spilled methane in the Deep Gulf of Mexico"," Science, vol. 332, no. 6033, pp. 1033-d, 2011.

[59] T. B. Ryerson, K. C. Aikin, W. M. Angevine et al., "Atmospheric emissions from the deepwater Horizon spill constrain airwater partitioning, hydrocarbon fate, and leak rate," Geophysical Research Letters, vol. 38, no. 7, Article ID L07803, 2011.

[60] T. B. Ryerson, R. Camilli, J. D. Kessler et al., "Chemical data quantify Deepwater Horizon hydrocarbon flow rate and environmental distribution," Proceedings of the National Academy of Sciences of the United States of America, vol. 109, no. 50, pp. 20246-20253, 2012.

[61] S. A. Yvon-Lewis, L. Hu, and J. Kessler, "Methane flux to the atmosphere from the Deepwater Horizon oil disaster," Geophysical Research Letters, vol. 38, no. 1, Article ID L01602, 2011.

[62] Y. Zhang, H.-D. Zhao, W.-D. Zhai, K.-P. Zang, and J.-Y. Wang, "Enhanced methane emissions from oil and gas exploration areas to the atmosphere - The central Bohai Sea," Marine Pollution Bulletin, vol. 81, no. 1, pp. 157-165, 2014.

[63] S. B. Dalsøren, C. L. Myhre, G. Myhre et al., "Atmospheric methane evolution the last 40 years," Atmospheric Chemistry and Physics, vol. 16, no. 5, pp. 3099-3126, 2016.

[64] C. L. Myhre, B. Ferré, S. M. Platt et al., "Extensive release of methane from Arctic seabed west of Svalbard during summer 2014 does not influence the atmosphere," Geophysical Research Letters, vol. 43, no. 9, pp. 4624-4631, 2016.

[65] S. Dupré, L. Berger, N. Le Bouffant, C. Scalabrin, and J.-F. Bourillet, "Fluid emissions at the Aquitaine Shelf (Bay of Biscay, France): A biogenic origin or the expression of hydrocarbon leakage?" Continental Shelf Research, vol. 88, pp. 24-33, 2014.

[66] S. Dupré, B. Loubrieu, C. Scalabrin et al., "Discovery of widespread biogenic methane emissions and authigenic carbonate mound-like structures at the aquitaine shelf (Bay of Biscay)," in Proceedings of the AGU Fall Meeting, December 2014. 
[67] J.-J. Biteau, A. Le Marrec, M. Le Vot, and J.-M. Masset, "The Aquitaine Basin," Petroleum Geoscience, vol. 12, no. 3, pp. 247273, 2006.

[68] C. Pierre, M.-M. Blanc-Valleron, and S. Dupré, "Methane derived authigenic carbonates from the upper continental margin of the Bay of Biscay (France)," in Proceedings of the AGU Fall Meeting Abstracts, p. 1099, 2014.

[69] C. Pierre, J. Demange, M.-M. Blanc-Valleron, and S. Dupré, "Authigenic carbonate mounds from active methane seeps on the southern Aquitaine Shelf (Bay of Biscay, France): evidence for anaerobic oxidation of biogenic methane and submarine groundwater discharge during formation," Continental Shelf Research, vol. 133, pp. 13-25, 2017.

[70] N. Lanteri and L. Bignon, Device for taking pressurized samples, European Patent WO/2007/128891 (2007) www.wipo .int/patentscope/search/fr/WO2007128891.

[71] Y. Chen, S. Wu, Y. Xie, C. Yang, and J. Zhang, "A novel mechanical gas-tight sampler for hydrothermal fluids," IEEE Journal of Oceanic Engineering, vol. 32, no. 3, pp. 603-608, 2007.

[72] H. Huang, C. Yang, S. Chen et al., "Novel gas-tight multisampler for discrete deep-sea water," Chinese Journal of Mechanical Engineering (English Edition), vol. 25, no. 4, pp. 722-728, 2012.

[73] J. S. Seewald, K. W. Doherty, T. R. Hammar, and S. P. Liberatore, "Erratum: A new gas-tight isobaric sampler for hydrothermal fluids (Deep-Sea Research I (2002) 49 (189-196) PII:S0967063701000462)," Deep-Sea Research Part I: Oceanographic Research Papers, vol. 49, no. 6, p. 1117, 2002.

[74] S.-J. Wu, C.-J. Yang, and C.-T. A. Chen, "A handheld sampler for collecting organic samples from shallow hydrothermal vents," Journal of Atmospheric and Oceanic Technology, vol. 30, no. 8, pp. 1951-1958, 2013.

[75] S.-J. Wu, C.-J. Yang, H.-C. Huang, and Y. Chen, "Development of an electric control gas-tight sampler for seafloor hydrothermal fluids," Journal of Zhejiang University: Science A, vol. 15, no. 2, pp. 120-129, 2014.

[76] M. Römer, H. Sahling, T. Pape et al., "Methane fluxes and carbonate deposits at a cold seep area of the Central Nile Deep Sea Fan, Eastern Mediterranean Sea," Marine Geology, vol. 347, pp. 27-42, 2014.

[77] E. J. Sauter, S. I. Muyakshin, J.-L. Charlou et al., "Methane discharge from a deep-sea submarine mud volcano into the upper water column by gas hydrate-coated methane bubbles," Earth and Planetary Science Letters, vol. 243, no. 3-4, pp. 354-365, 2006.

[78] M. Römer, H. Sahling, T. Pape, G. Bohrmann, and V. Spieß, "Quantification of gas bubble emissions from submarine hydrocarbon seeps at the Makran continental margin (offshore Pakistan)," Journal of Geophysical Research: Oceans, vol. 117, no. 10, Article ID C10015, 2012.

[79] M. Römer, H. Sahling, T. Pape et al., "Geological control and magnitude of methane ebullition from a high-flux seep area in the Black Sea-the Kerch seep area," Marine Geology, vol. 319-322, pp. 57-74, 2012.

[80] M. E. Torres, J. McManus, D. E. Hammond et al., "Fluid and chemical fluxes in and out of sediments hosting methane hydrate deposits on Hydrate Ridge, OR, I: Hydrological provinces," Earth and Planetary Science Letters, vol. 201, no. 3-4, pp. 525-540, 2002.

[81] M. Hovland and A. G. Judd, "The global production of methane from shallow submarine sources," Continental Shelf Research, vol. 12, no. 10, pp. 1231-1238, 1992.
[82] K. Gürgey, R. P. Philp, C. Clayton, H. Emiroğlu, and M. Siyako, "Geochemical and isotopic approach to maturity/source/ mixing estimations for natural gas and associated condensates in the Thrace Basin, NW Turkey," Applied Geochemistry, vol. 20, no. 11, pp. 2017-2037, 2005.

[83] J.-X. Dai, Y. Song, C.-S. Dai, and D.-R. Wang, "Geochemistry and accumulation of carbon dioxide gases in China," AAPG Bulletin, vol. 80, no. 10, pp. 1615-1626, 1996.

[84] J. M. Hunt, R. J. Miller, and J. K. Whelan, "Formation of C4-C7 hydrocarbons from bacterial degradation of naturally occurring terpenoids," Nature, vol. 288, no. 5791, pp. 577-578, 1980.

[85] S. W. Taylor, B. S. Lollar, and L. I. Wassenaar, "Bacteriogenic ethane in near-surface aquifers: implications for leaking hydrocarbon well bores," Environmental Science and Technology, vol. 34, no. 22, pp. 4727-4732, 2000.

[86] D. Rowe and A. Muehlenbachs, "Low-temperature thermal generation of hydrocarbon gases in shallow shales," Nature, vol. 398, no. 6722, pp. 61-63, 1999.

[87] C. Bourry, B. Chazallon, J. L. Charlou et al., "Free gas and gas hydrates from the Sea of Marmara, Turkey. Chemical and structural characterization," Chemical Geology, vol. 264, no. 1-4, pp. 197-206, 2009.

[88] R. Sassen, S. Joye, S. T. Sweet, D. A. Defreitas, A. V. Milkov, and I. R. MacDonald, "Thermogenic gas hydrates and hydrocarbon gases in complex chemosynthetic communities, Gulf of Mexico continental slope," Organic Geochemistry, vol. 30, no. 7, pp. 485497, 1999.

[89] C. Vandré, B. Cramer, P. Gerling, and J. Winsemann, "Natural gas formation in the western Nile delta (Eastern Mediterranean): Thermogenic versus microbial," Organic Geochemistry, vol. 38, no. 4, pp. 523-539, 2007.

[90] J. W. Pohlman, E. A. Canuel, N. R. Chapman, G. D. Spence, M. J. Whiticar, and R. B. Coffin, "The origin of thermogenic gas hydrates on the northern Cascadia Margin as inferred from isotopic $(13 \mathrm{C} / 12 \mathrm{C}$ and $\mathrm{D} / \mathrm{H})$ and molecular composition of hydrate and vent gas," Organic Geochemistry, vol. 36, no. 5, pp. 703-716, 2005.

[91] G. Etiope, A. Feyzullayev, A. V. Milkov, A. Waseda, K. Mizobe, and C. H. Sun, "Evidence of subsurface anaerobic biodegradation of hydrocarbons and potential secondary methanogenesis in terrestrial mud volcanoes," Marine and Petroleum Geology, vol. 26, no. 9, pp. 1692-1703, 2009.

[92] I. M. Head, D. M. Jones, and S. R. Larter, "Biological activity in the deep subsurface and the origin of heavy oil," Nature, vol. 426, no. 6964, pp. 344-352, 2003.

[93] D. M. Jones, I. M. Head, N. D. Gray et al., "Crude-oil biodegradation via methanogenesis in subsurface petroleum reservoirs," Nature, vol. 451, no. 7175, pp. 176-180, 2008.

[94] R. J. Pallasser, "Recognizing biodegradation in gas/oil accumulations through the $\delta 13 \mathrm{C}$ compositions of gas components," Organic Geochemistry, vol. 31, no. 12, pp. 1363-1373, 2000.

[95] L. Ruffine, O. Fandino, J. Etoubleau et al., "Geochemical dynamics of the natural-gas hydrate system in the Sea of Marmara, offshore Turkey," in Advances in Natural Gas Technology, pp. 2956, 2012.

[96] J. Choi, J.-H. Kim, M. E. Torres et al., "Gas origin and migration in the Ulleung Basin, East Sea: Results from the Second Ulleung Basin Gas Hydrate Drilling Expedition (UBGH2)," Marine and Petroleum Geology, vol. 47, pp. 113-124, 2013.

[97] A. Prinzhofer and É. Pernaton, "Isotopically light methane in natural gas: Bacterial imprint or diffusive fractionation?" Chemical Geology, vol. 142, no. 3-4, pp. 193-200, 1997. 
[98] W. S. Reeburgh, "Methane consumption in Cariaco Trench waters and sediments," Earth and Planetary Science Letters, vol. 28, no. 3, pp. 337-344, 1976.

[99] M. Y. Yoshinaga, T. Holler, T. Goldhammer et al., "Carbon isotope equilibration during sulphate-limited anaerobic oxidation of methane," Nature Geoscience, vol. 7, no. 3, pp. 190-194, 2014. 

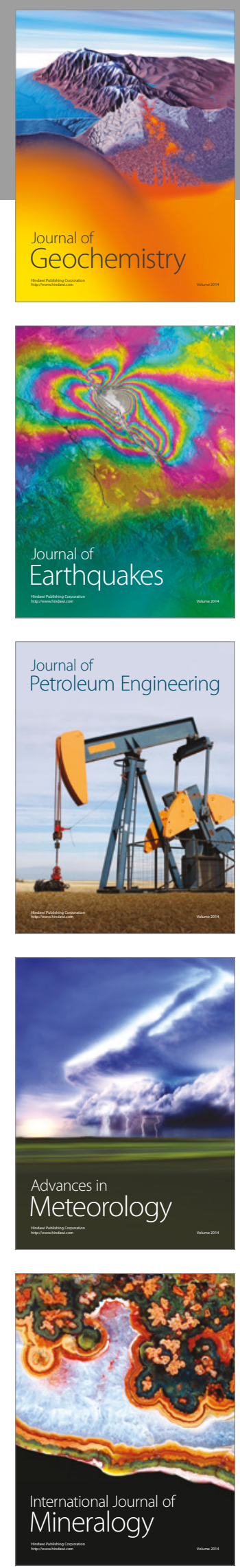
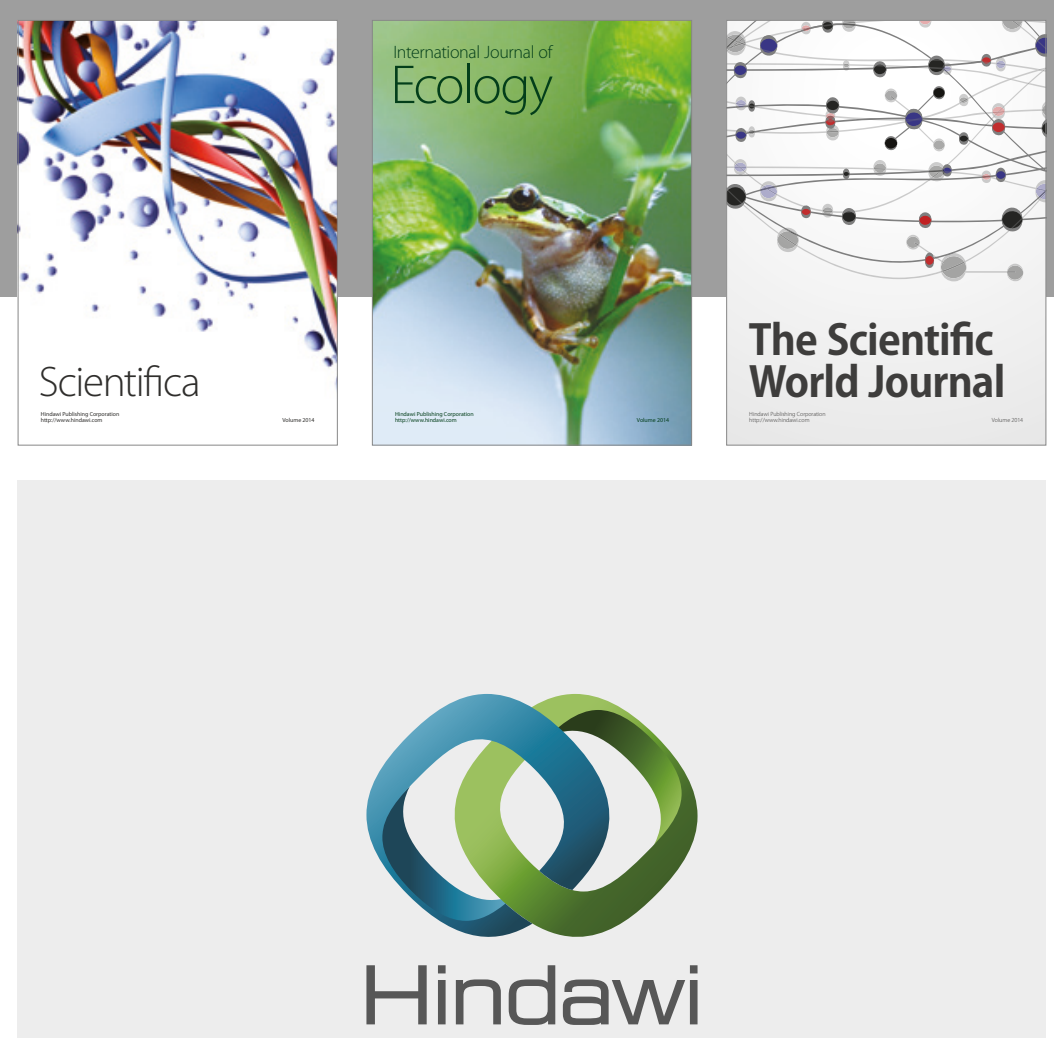

Submit your manuscripts at

https://www.hindawi.com
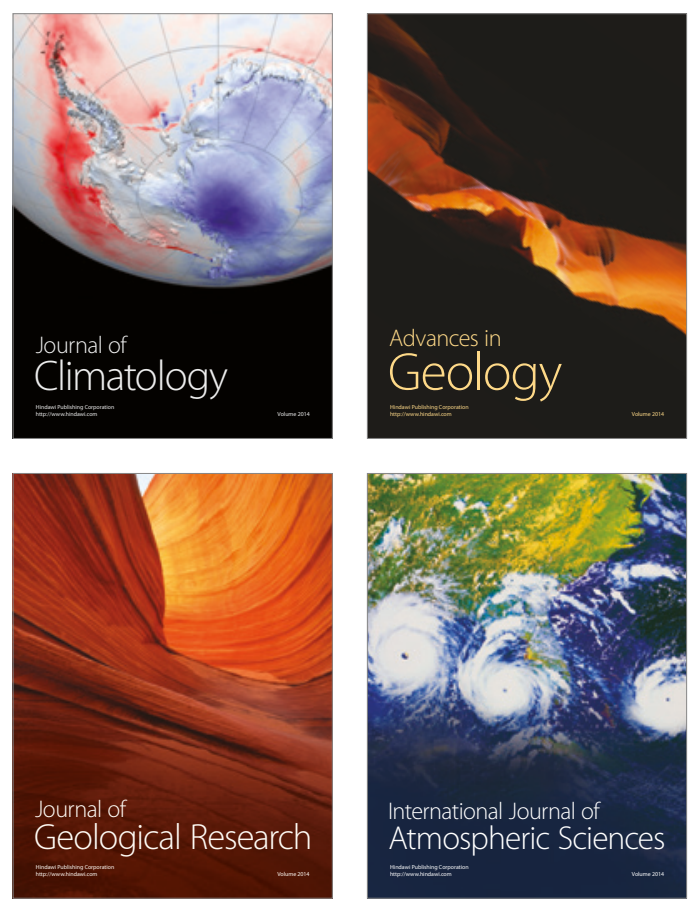

The Scientific

World Journal
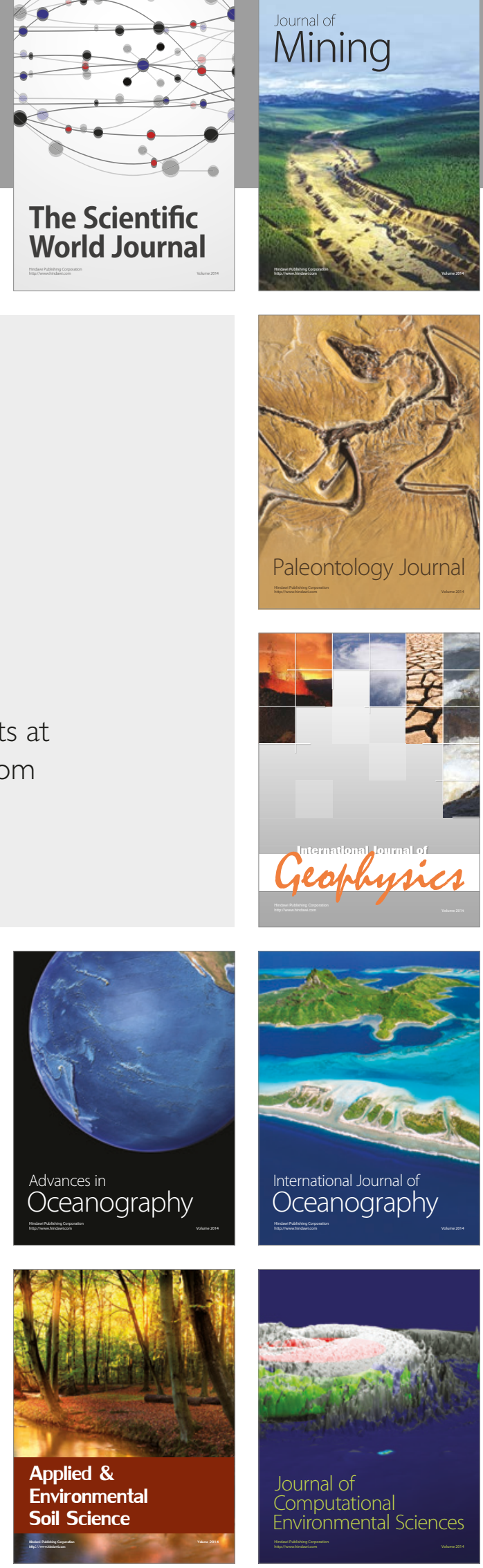